JÓZEF FISZER

DOI : 10.14746/rie.2015.9.3

Uniwersytet Warszawski

\title{
Unia Europejska dziś i jej niepewna przyszłość. Cz. I
}

\begin{abstract}
Wstep
Nie ulega wątpliwości, że powojenna integracja europejska jest w historii współczesnego świata procesem bez precedensu. Również bez precedensu jest będąca efektem tego procesu Unia Europejska, która jest organizacją międzynarodową, jednak nietypową ze względu na swoje cele i funkcje. Nie jest też państwem, ale organizacją specyficzną, integrującą zarówno państwa, jak i ludzi, łączącą w sobie tylko pewne cechy państwa oraz organizacji międzynarodowej. Jest dobrowolnym związkiem suwerennych i demokratycznych państw. Unia, w odróżnieniu od klasycznej organizacji międzynarodowej, pełni w szerokim zakresie funkcje prawodawcze, będące podstawową przesłanką jej istnienia. Upodabnia się tym samym do państwa (zwłaszcza federalnego), ponieważ wykonuje władzę publiczną skutkującą aktami prawnymi stosowanymi pośrednio i adresowanymi nie tylko do państw, lecz również do osób fizycznych i prawnych. Legitymizacja źródeł władzy UE wynika zaś z traktatów założycielskich, ratyfikowanych przez wszystkie państwa członkowskie. Władza ta opiera się na powierzaniu Unii przez państwa określonych kompetencji władzy publicznej (art. 5 TUE, art. 90 Konstytucji RP) (Kranz, Wyrozumska, 2012, s. 20-36; Kubin, 2014). Wielu autorów, m.in. David Beetham i Christopher Lord podkreślają, że zagadnienie legitymizacji systemu instytucjonalnego UE jest wciąż aktualne (ang. in play), gdyż dotyczy ciagłych zmian w UE, która w związku z tym przejmuje nowe kompetencje, jakie wcześniej wykonywane były przez państwa członkowskie (Beetham, Lord, 1998, s. 125).

Unia Europejska w świetle teorii neofunkcjonalnej jest samonapędzającym się mechanizmem, którego istota polega na tym, że każdy etap jej ewolucji pociąga za sobą konieczność dalszych kroków (spillover), czyli zwiększania jej kompetencji (pogłębianie integracji). Prowadzi to do stałych napięć wywoływanych zakresem i tempem zmian, definiowaniem narodowych interesów oraz pojmowaniem demokracji i suwerenności. Jest to przede wszystkim problem polityczny, a w mniejszym stopniu prawny. W relacjach międzynarodowych nie ma jednak i zapewne długo nie będzie światowego parlamentu, sądów czy rządu. Powstanie tego typu instytucji możliwe jest tylko za traktatową zgodą wszystkich państw, co zresztą ma miejsce, ale tylko w ograniczonym rzeczowo lub geograficznie zakresie (Finkelstein, 1995, s. 368; Lipschutz, 1997, s. 83; Czaputowicz, 2007, s. 354-358).

Klasyczna analiza natury Unii Europejskiej dowodzi, że jest to byt polityczny sui generis, o charakterze hybrydowym, czyli usytuowany pomiędzy konfederacją a federacją, ale w sposób nietypowy z punktu widzenia podziału kompetencji między po-
\end{abstract}


ziomem krajowym i europejskim (ponadnarodowym). Dopóki UE będzie strukturą właśnie sui generis, w której wypadku będziemy mieć do czynienia z kombinacją cech charakterystycznych dla międzyrządowej organizacji międzynarodowej, organizacji ponadnarodowej i państwa, dopóty także legitymizacja tej struktury powinna mieć charakter szczególny, w którym ,legitymizacja demokratyczna odgrywa rolę wiodąca, ale jest uzupełniana przez inne źródła, dzięki którym funkcjonowanie systemu instytucjonalnego UE, i całej UE, będzie mogło być uznane za prawomocne" (Kubin, 2014, s. 18).

W ostatnich latach coraz częściej formułowane są postulaty dalszej federalizacji Unii Europejskiej, co pozwoliłoby na przezwyciężenie jej inercji, w tym również kryzysu gospodarczo-społecznego i politycznego oraz wzmocnienie pozycji Europy na arenie międzynarodowej. $Z$ drugiej strony, wielu badaczy wskazuje, że formuła federalna (ustrój) nie jest adekwatna dla istoty unijnej rzeczywistości, w tym dynamizacji procesów różnicowania się integracji europejskiej. Przekonują oni, że bardziej użyteczną dla Unii Europejskiej formułą będzie imperium, definiowane poprzez relacje asymetrii między centrum i peryferiami, zmienną strukturę przestrzenną, determinowaną ekspansją terytorialną oraz logiką dwupoziomowej tożsamości - tożsamość narodowa (krajowa) oraz tzw. misja cywilizacyjna (Beck, 2009, s. 34-35; Gravier, 2011, s. 123-125).

Kryzys finansowo-gospodarczy w Europie i kryzys polityczny na Ukrainie pokazują wyraźnie, że dotychczasowy ustrój Unii Europejskiej nie zdaje już egzaminu, a jej polityki - tak wewnętrzna, jak i zewnętrzna - nie są skuteczne. Unia boryka się z problemem faktycznie nieograniczonych i niejasnych kompetencji formalnych, przy jednoczesnym braku zasobów niezbędnych do ich realizacji. Unijni decydenci podejmują się ambitnych projektów, jak na przykład unia gospodarczo-walutowa czy wspólna polityka zagraniczna i obrony, ale bez oglądania się na obiektywne ograniczenia i możliwości ich zrealizowania. Wyłaniają się nowe linie podziału, a największe państwa Unii Europejskiej, w tym Francja i Niemcy, tandem, który do tej pory stanowił jej lokomotywę, coraz głośniej obnoszą się z poczuciem krzywdy i słabnącą wiarą w sens napędzania tej całej trzeszczącej maszynerii, jaką dziś przypomina Unia i są przeciwne jej poszerzaniu i pogłębianiu. Według sondaży, aż 73\% Niemców dziś jest zdania, że ich kraju nie stać już na większe zaangażowanie w proces ratowania euro i większy wysiłek w budowaniu zjednoczonej Europy (Garczewski, 2015, s. 21-40). Tymczasem wiadomo, że bez dalszego niemieckiego i francuskiego zaangażowania w rozwiązywanie unijnych problemów, federalny „projekt europejski” skazany będzie na niepowodzenie. Na federalizację Europy sceptycznie patrzy też wiele innych państw członkowskich, obawiając się nie tylko utraty wywalczonych na gruncie dotychczasowych regulacji w UE przywilejów, czego najlepszym przykładem jest postawa Wielkiej Brytanii, a z drugiej strony lękających się przed zwiększeniem roli RFN w „nowej”, bardziej scentralizowanej instytucjonalnie Europie (Garczewski, 2015, s. 39). Marine Le Pen, szefowa Frontu Narodowego we Francji, który cieszy się coraz większym poparciem społecznym, nie kryje, że dąży do upadku Unii Europejskiej, określając ją jako „sowiecką Unię Europejską”, która „ukradła suwerenność” i ogranicza możliwości „samostanowienia przez władze narodowe” (Grosse, 2014, s. A11).

Napięcia geopolityczne między Paryżem i Berlinem oraz między Waszyngtonem i Berlinem doprowadziły do turbulencji w procesach integracyjnych Europy i również 
sprzyjają narastaniu nastrojów eurosceptycznych w UE. Pokazują to sondaże opinii społecznej, przeprowadzane przez Komisję Europejską. Od początku kryzysu w 2008 roku systematycznie spada zaufanie do władz publicznych, zarówno tych europejskich, jak i narodowych. Jednak silniej do instytucji unijnych (spadek o blisko 30\% między rokiem 2007 a 2012; w tym samym okresie spadek zaufania do władz narodowych wyniósł średnio około 20\%) (Grosse, 2014, s. A11).

Dziś w Unii Europejskiej mamy coraz mniej solidarności, zaufania, spójności i wiary oraz optymizmu co do jej perspektyw. Wrogami Unii są dziś nie tylko eurosceptycy, ale także realiści, którzy bez trudu znajdują argumenty, że to wszystko źle działa, a więc trzeba dbać o własne interesy i wyrwać, co się da, a przynajmniej nie dać sobie wyrwać. Taką egoistyczną i roszczeniową postawę od lat zajmuje w UE Wielka Brytania, a co nasiliło się pod rządami konserwatywnego premiera Davida Camerona, który straszy, że wyprowadzi ją z Unii i w tym celu zapowiedział przeprowadzenie referendum w 2017 roku. Cameron cynicznie gra na antyimigranckich nastrojach, które wzmacniają antyunijne tendencje w Europie. Fatalne stosunki D. Camerona z Brukselą utrudniały też wypracowanie wspólnej polityki UE wobec Moskwy. Po zwycięskich wyborach parlamentarnych w dniu 7 maja 2015 roku i spektakularnym w nich sukcesie D. Camerona zwiększyła się groźba Brexitu, czyli wyjścia Wielkiej Brytanii z Unii Europejskiej, co mocno uderzyłoby w geopolityczne znaczenie UE na świecie i podmyłoby jej fundamenty (Bielecki, 2015, s. 2; Czarnecki, 2015, s. 10). Tymczasem pogrążona w licznych kryzysach, zmęczona i będąca na rozdrożu Unia Europejska potrzebuje dzisiaj nowej aksjologii, odświeżenia zapomnianych słów, pojęć i emocji, które w przeszłości motywowały do wysiłków na rzecz budowy bezpiecznej, zjednoczonej, demokratycznej i bogatej Europy. Potrzebuje przede wszystkim nowych wielkich przywódców, wizjonerów, zdolnych do przedstawienia porywających wizji (Malendowski, 2010, s. 7-20; Smoczyński, 2011, s. 23; Baczyński, 2011, s. 34).

Najwyższa pora, aby w Unii Europejskiej rozpocząć o powyższych kwestiach poważną debatę, a zwłaszcza debatę na temat jej ideologii i podstawowych wartościach. O tym, czym jest dziś faktycznie i czym powinna być europejska tożsamość, odpowiedzialność i solidarność. Jakie obowiązi nakłada ona na bogatszych, a jakie na uboższych członków unijnej rodziny. Bez wiarygodnego nazwania, przypomnienia bądź odkrycia na nowo owej europejskiej tożsamości, Unia nie będzie mogła normalnie funkcjonować, rozwiązywać skutecznie swych gospodarczych, społecznych i politycznych problemów, powiększać i rozwijać się oraz modernizować, a w rezultacie tego dojdzie do jej jeszcze większego paraliżu, a być może nawet rozpadu, albo stanie się ona co najwyżej strefą wolnego handlu, jak przewiduje to znany ekspert George Friedman w swojej książce pt. Następna dekada. Gdzie byliśmy i dokąd zmierzamy (Friedman, 2012, s. 234). A na to tylko czeka Rosja, która od lat wspiera antyunijne siły w Europie (Prus, 2015, s. 16-18).

\footnotetext{
Rosja utrzymuje bliskie kontakty ze skrajną prawicą w Europie, m.in. z takimi ugrupowaniami, jak francuski Front Narodowy, węgierski Jobbik, austriacka FPÖ, grecki Złoty Świt, belgijski Vlaamas Balang, bułgarska Ataka. Ich liderzy są zapraszani do Moskwy na występy w Dumie, wykłady na uniwersytetach, spotkania z politykami różnego szczebla.
} 
Kryzys finansowo-gospodarczy obnażył również wiele innych słabości Unii Europejskiej, a zwłaszcza bezsilność technokratycznego zarządzania unijnymi politykami oraz ujawnił faktyczne ośrodki władzy w skomplikowanym unijnym systemie politycznym, w którym codzienna działalność nie zawsze wskazuje na pierwszy rzut oka centra podejmowania kluczowych decyzji. Przede wszystkim ujawnił słabość decyzyjną czołowego organu ponadnarodowego Unii Europejskiej, czyli Komisji Europejskiej i bezsilność jej przewodniczącego. Kryzys ten, bezprecedensowy w najnowszych dziejach Europy i UE, pokazał również słabość czynnika międzyrządowego oraz istniejące wciąż w Unii Europejskiej podziały, egoizmy i partykularyzmy. W większości krajów Europy obywatele stracili do niej zaufanie, a proces dezintegracji nasila się. Dzieje się tak dlatego, że UE nie ma charyzmatycznych przywódców, wizjonerów ani wybitnych polityków. Kierują nią dziś biurokraci i partyjni działacze, oderwani od ludzi i ich potrzeb. Zaś jej system polityczny jest ułomny i wymaga głębokich zmian. Musi się on zmienić i to jak najszybciej. Unia Europejska chcąc przetrwać musi ewoluować w kierunku państwa obywatelskiego i socjalnego (Fiszer, 2014, s. 101-125; Ruszkowski, Wojnicz, 2013).

Już na początku XXI wieku wielu badaczy, decydentów i publicystów, a przede wszystkim reprezentantów różnych grup społecznych ostrzegło, że tradycyjny model stosunków międzynarodowych jest niewystarczający dla ujęcia kształtującego się, i trudnego do scharakteryzowania, globalnego porządku politycznego, opartego w dużej mierze na wyspecjalizowanych instytucjach działających ponad granicami państwa. Zarówno państwowi, jak również pozapaństwowi aktorzy stosunków międzynarodowych stanęli przed koniecznością odnalezienia swojego miejsca w rzeczywistości, która jawi się jako coraz mniej klarowna i „ponowoczesna” (Łoś-Nowak, 2011, s. 25-31; Pietraś, 2008, s. 57-75).

Procesy globalizacyjne, determinujące dziś międzynarodową integrację powodują, iż państwa nie są w stanie rozwiazywać wielu problemów i rozwijać się samodzielnie. Szanse i zagrożenia mają obopólny charakter transgraniczny, a rola państwa nieuchronnie się zmienia. Utrata lub ograniczenie pewnych kompetencji mogą jednak zostać zrekompensowane nowymi możliwościami w międzynarodowej współpracy (prawo i organizacje międzynarodowe). Wymogi demokracji przenoszą się tym samym z poziomu państwa na różną od niego płaszczyznę międzynarodową. W rezultacie tego Unia Europejska powoli upodabnia się do państwa, jednak jest odrębnym od niego podmiotem prawnym. Instytucje międzynarodowe $z$ natury rzeczy pozostają zawsze w pewnej opozycji (konkurencji) wobec instytucji narodowych. Z kolei państwa i narody nie są w Unii Europejskiej zagrożone, gdyż integracja utrudnia ich izolację lub peryferyzację oraz przyczynia się do wzrostu ich dobrobytu oraz zapewnia im szeroko rozumiane bezpieczeństwo.

Nie ulega wątpliwości, że po sześćdziesięciu latach od powstania pierwszych Wspólnot i ponad dwudziestu latach od utworzenia Unia Europejska potrzebuje nowej wizji rozwoju i strategii działania oraz daleko idącej modernizacji i demokratyzacji. Dziś musimy odpowiedzieć sobie nie tylko na pytanie, czy model demokracji w państwie może być wzorem dla Unii Europejskiej oraz czy Unia powinna stać się państwem (mocarstwem), ale przede wszystkim musimy odpowiedzieć na pytanie, co należy uczynić, aby obywatele nadal chcieli Unii i aby nie doszło do jej rozpadu (Fiszer, 2014, s. 101-125). 
Należy uczynić wszystko, aby UE była aktywnym podmiotem na arenie międzynarodowej i odgrywała istotną rolę w budowie nowego ładu międzynarodowego, którego powinna być jednym z głównych filarów. W tym celu niezbędna jest jedność i współpraca wszystkich państw należących do Unii Europejskiej, a zwłaszcza RFN i Francji. Niezbędna też jest dalsza współpraca UE i Stanów Zjednoczonych oraz UE i NATO. Jeśli zaś nie zostanie ona zintensyfikowana, to system euroatlantycki utraci swoje znaczenie i przestanie być gwarantem bezpieczeństwa Zachodu. Wobec bankructwa dotychczasowej polityki wschodniej Unii, trzeba też wypracować nowy kształt współpracy oraz polityki UE i NATO wobec Rosji oraz przyjąć nową, dalekowzroczną transatlantycką strategię wobec tego kraju (Krzemiński, 2014, s. 43-45).

Walka o przyszłość Ukrainy zdestabilizowała bowiem środowisko międzynarodowe w bezpośrednim sąsiedztwie unijnych granic, a część państw po raz pierwszy od zakończenia zimnej wojny dostrzega groźbę rosyjskiej agresji. Jest to dziś sytuacja niepokojąca dla Europejczyków, którzy obdarzeni kilkoma dekadami pokoju wykluczyli już możliwość konfliktu zbrojnego na naszym kontynencie. Teraz powinno nastapić na nowo zdefiniowanie roli UE w polityce obronnej oraz w relacjach z NATO i Stanami Zjednoczonymi. Należy jak najszybciej przyjąć wspólną strategię, aby zabezpieczyć Europę i świat przed imperialnymi zakusami prezydenta Rosji, który chce przywrócić Rosji pozycję globalnego mocarstwa oraz odzyskać wpływy na terenach postsowieckich, tworząc w tym celu Unię Euroazjatycką, mającą ograniczyć wpływy UE i Stanów Zjednoczonych w Europie i na świecie. Władimir Putin już od dawna prowadzi agresywną politykę na rzecz odbudowania wpływów radzieckiego imperium. Marzy mu się ponowne przyłączenie krajów, które po rozpadzie ZSRR wymknęły się spod kontroli Kremla. Na celowniku były już Czeczenia, Gruzja, Białoruś, Armenia, a teraz Ukraina. Naruszona została terytorialna integralność suwerennego państwa, złamano zasady Karty Narodów Zjednoczonych i Aktu Końcowego KBWE oraz podstawowe zasady prawa międzynarodowego. W świetle prawa międzynarodowego przyłączenie wchodzącego w skład terytorium Ukrainy Półwyspu Krymskiego (Krymu) do Federacji Rosyjskiej należy kwalifikować jako aneksję, tj. nielegalne nabycie terytorium innego państwa w drodze użycia i/lub groźby użycia siły zbrojnej. Federacja Rosyjska naruszyła też swoje zobowiązania prawne wobec całej społeczności międzynarodowej (Opinia Doradczego Komitetu, 2014, s. 121-131). De facto zburzony został cały dotychczasowy ład międzynarodowy. Kolejnymi ofiarami jego polityki mogą być kraje nadbaltyckie (Nowak, 2014; Wójcik, 2015, s. 22-24; Siła rzqdzi, 2015, s. A8-A9). Jak pisze wybitny znawca Rosji, profesor Richard Pipes, działania Putina są racjonalne w kontekście rosyjskiej historii, bo Rosjanie lubią silnych przywódców, a on tę rolę znakomicie wypełnia. W ich optyce „tylko Rosja sprzeciwiająca się Stanom Zjednoczonym pozostaje wielkim mocarstwem. Rosjanie mogą być głodni, ale dopóki mają poczucie mocarstwowości, wszystko jest w porządku" (Sila rzqdzi, 2015, s. A8).

Z drugiej strony, biorąc pod uwagę fakt, że we współczesnym świecie, w którym decydują twardo definiowane interesy państw, zwłaszcza mocarstw, trzeba się z nimi liczyć. Tym bardziej, jak pokazuje to niniejsza analiza, dziś nadal dużą przydatność eksplanacyjną w badaniu rzeczywistości międzynarodowej zachowuje paradygmat realistyczny, który dowodzi, że świat współczesny szybko się zmienia i na naszych oczach powstaje nowy ład międzynarodowy, w którym główną rolę zaczynają odgry- 
wać tzw. mocarstwa wschodzące, zaliczane do grupy BRIC, tj. Brazylia, Rosja, Indie oraz Chiny. W przeciwieństwie do Stanów Zjednoczonych i Unii Europejskiej, kryzys finansowo-gospodarczy nie osłabił znacznie potencjału ekonomicznego strefy BRIC. Pomimo zauważalnego, zwłaszcza w roku 2008, załamania głównych wskaźników makroekonomicznych oraz wyhamowania ich wzrostu w latach kolejnych, kraje te wciąż stanowią ewenement na skalę światową jeżeli chodzi o wzrost gospodarczy. Według ekspertów trend ten utrzyma się jeszcze przez kilka dziesięcioleci, co ostatecznie pozwoli krajom BRIC - ze szczególnym wskazaniem na Chiny - zająć dotychczasową pozycję gospodarczą rozwiniętych państw świata zachodniego. Wpadając w coraz to większą spiralę długu publicznego tracą one bowiem swoją ledwie widoczną już dominację. Według prognoz na rok 2050 lista krajów z najwyższym PKB będzie wyglądać następująco: Chiny, USA, Indie, Brazylia, Meksyk oraz Rosja. Kraje grupy BRIC zajmują dziś około $25 \%$ powierzchni Ziemi, którą zamieszkuje $40 \%$ ludności świata, a ich PKB wynosi około $3 / 5$ produktu krajowego Stanów Zjednoczonych, ale po zastosowaniu wskaźnika parytetu siły nabywczej już nieznacznie go przekracza (Mroziewicz, 2015, s. 14-17; Karpienia, 2013, s. 192-217).

W związku z tym, jak pisze Ryszard Zięba: ,Jest więc kwestią strategicznego wyboru, przed jakim stoi Zachód. Czy samodzielnie, a do tego spychając Rosję na pozycję podrzędna, jest w stanie sprostać wyzwaniom bieżącym, jakie stwarza konflikt bliskowschodni i przybierający na sile fundamentalizm islamski, a przede wszystkim czy zdoła podjać długofalowe wyzwanie, jakie niesie wzrost znaczenia Chin czy Indii. $\mathrm{Pa}-$ radoksalnie kryzys ukraiński powinien uświadomić wszystkim zaangażowanym podmiotom zewnętrznym, że porozumienie się Zachodu z Rosją w sprawie Ukrainy może mieć przełomowe pozytywne znaczenie dla całego globalnego ładu międzynarodowego" (Zięba, 2014, s. 39-40; Kuźniar, 2014, s. 41-56; Góralczyk, 2014).

Od ponad 65. lat, kolejne pokolenia Europejczyków są świadkami pokojowego konstruowania jedności kontynentu. Zaś od ponad 25. lat, w procesie tym uczestniczą również państwa Europy Środkowo-Wschodniej, w tym także Polska, które po II wojnie światowej znalazły się po ,ciemnej stronie” żelaznej kurtyny. Beneficjentami integracji europejskiej są dziś wszyscy Europejczycy, także miliony Polaków, którzy należą do najbardziej entuzjastycznych względem Unii narodów Europy. Dziś jednak Unia przeżywa szereg trudności, które wręcz można nazwać kryzysami: politycznym, gospodarczym, społecznym, aksjologii i strukturalnym, a co poważnie hamuje jej aktywność na forum międzynarodowym. Ostatnie lata, to jeden z najtrudniejszych okresów w historii europejskiej integracji, na którą cieniem kładą się takie zjawiska i procesy, jak: wciąż nieprzezwyciężony kryzys finansowy i gospodarczy w strefie euro, napięcia w stosunkach $\mathrm{z}$ Rosją z powodu sytuacji we wschodniej Ukrainie, zagrożenia płynące z niestabilnej sytuacji w basenie Morza Śródziemnego oraz na Bliskim i Środkowym Wschodzie, migracje i imigranci, których liczba rośnie po tzw. arabskiej wiośnie ludów i utworzeniu Państwa Islamskiego. Konflikty wewnętrzne i międzynarodowe spowodowały, że w 2014 roku aż $38 \mathrm{mln}$ ludzi na świecie nie mogło przebywać w swoich domach. To o ponad $14 \%$ więcej niż w roku poprzednim ${ }^{2}$.

2 Tak wynika z opublikowanego w Genewie raportu Centrum Monitoringu Wewnętrznych Migracji, w: „Gazeta Wyborcza”, 7 V 2015. 
Celem niniejszego artykułu jest pokazanie atutów UE oraz jej słabości, które przesądzają o jej pozycji na arenie międzynarodowej i determinują jej stanowisko wobec wydarzeń zachodzących dziś na świecie, a szczególnie jeśli idzie o kryzys na Ukrainie, który zagraża bezpieczeństwu Europy i hamuje proces budowy multipolarnego ładu globalnego. Kryzys ten bowiem i agresja Rosji na suwerenną Ukrainę, tak jak agresja Stanów Zjednoczonych na Irak w 2003 roku, prowadzą do rozbicia solidarności, podziałów i nieporozumień między państwami należącymi do Unii Europejskiej. Ulegają też rozluźnieniu stosunki UE i Stanów Zjednoczonych, które do tej pory stanowiły fundament bezpieczeństwa i współpracy transatlantyckiej. To co dzieje się na Ukrainie, stanowi test dla UE i NATO. Pokazuje, na ile są one spójne i gotowe do współpracy oraz czy potrafią prowadzić wspólną politykę i mówić jednym głosem. Niestety, test ten dla UE i NATO jest niepomyślny. Mamy do czynienia z kryzysem Unii Europejskiej i NATO. Władimir Putin robi wszystko, by omijać Unię i rozmawiać z każdym krajem osobno i odnosi tu sukcesy dyplomatyczne oraz propagandowe. Moskwa zaś straszy UE i Amerykę nową wojną światową i w ten sposób powstrzymuje Zachód przed udzieleniem pomocy militarnej ofiarom rosyjskiej agresji (Czech, 2015, s. 10).

Artykuł ten pokazuje, że UE coraz bardziej traci na znaczeniu jako podmiot stosunków międzynarodowych i staje się coraz bardziej pasywnym aktorem na scenie międzynarodowej, odgrywa dziś raczej rolę drugoplanową. Jest wręcz lekceważona w Moskwie, Pekinie i Waszyngtonie oraz traktowana instrumentalnie przez Berlin, Paryż czy Londyn, a więc w stolicach państw, które mają największy wpływ na proces budowy nowego, multipolarnego ładu globalnego i jego bezpieczeństwo. Jednocześnie UE wykazuje brak zdecydowania, nie mówi jednym głosem na arenie międzynarodowej, nasilają się partykularyzmy państw członkowskich, a także ujawniają się jej inne mankamenty. Słabnie pozycja UE w organizacjach międzynarodowych. Na przykład, obecnie nie jest ona w ogóle reprezentowana w zarządzie Banku Światowego, nawet jako obserwator, co pozostaje w sprzeczności z prowadzoną przez nią na ogromną skalę polityką pomocy w rozwoju skierowaną do państw rozwijających się (Kołodziejczyk, 2013, s. 81-96; Holland, 2002). W związku z tym coraz częściej wysuwa się postulat przyznania UE w Banku Światowym statusu stałego obserwatora. W Zgromadzeniu Ogólnym ONZ UE jest obecnie jednym z 67 stałych obserwatorów. W praktyce przedstawiciele UE mogą zabrać głos dopiero po wypowiedzeniu się wszystkich zainteresowanych przedstawicieli reprezentujących 192 państwa członkowskie organizacji. Tylko w wyjątkowych okolicznościach Unii przyznaje się prawo zabrania głosu przed pozostałymi obserwatorami (Emmerson, 2011, s. 67; Rewizorski, 2015, s. 65).

Ostatnie wybory do Parlamentu Europejskiego, które odbyły się w dniach 22-25 maja 2014 roku pokazały, że Europejczycy, w tym również Polacy, są niezadowoleni i zagubieni i jest im dziś dużo trudniej wyobrazić sobie, jak Unia Europejska będzie wyglądała za dziesięć lat. Sondaże mówią, że ponad $60 \%$ Europejczyków obawia się, że ich dzieci będą miały gorsze życie niż oni sami (Mniej Europy, 2014, s. 23). Już dzisiaj w UE mamy niemałą rzeszę poszkodowanych, wykluczonych i obrażonych, którzy przyczyny niepowodzenia upatrują $\mathrm{w}$ miałkości i sprzedajności swoich elit i żądają by przestać ulegać dyktatowi kosmopolitycznych biurokratów i finansistów. Również przywódcy unijni są zagubieni, wręcz bezradni wobec takiej rzeczywistości. 
Zajmują się gospodarką w skali makro, a ludzie borykają się z problemami na poziomie codzienności. Przewodniczący Rady Herman Van Rompuy tuż po wyborach do Parlamentu Europejskiego stwierdził, że wyborcy „sformułowali silne przesłanie" i w związku z tym Rada musi dać ,jasne wytyczne" na przyszłość. W tórował mu przewodniczący Parlamentu Europejskiego Martin Schulz ostrzegając, że polityka nie jest w stanie wyegzekwować prymatu wobec wielonarodowych koncernów, a państwa członkowskie dają się łatwo rozgrywać przeciwko sobie przez innych wielkich graczy (Ostrowski, 2014, s. 58-60; Schulz, 2014).

Brak zdecydowanych działań Unia podniosła do rangi politycznego credo. Ma problemy z podejmowaniem decyzji. W sprawach ważnych jest powolna i niezdecydowana, a w sprawach drobnych jest pedantyczna i natrętna. Jest bierna nawet w kwestii własnego bezpieczeństwa, co doprowadza Amerykę do pasji. Kryzys na Ukrainie pokazał to, co wiadomo już od dawna, a mianowicie, że UE de facto nie ma żadnej wspólnej polityki zagranicznej i bezpieczeństwa oraz, że jest mocno podzielona. RFN i Francja oraz Wielka Brytania forsują w ramach UE własne interesy i to przy współpracy z Federacją Rosyjską a w opozycji do polityki międzynarodowej Stanów Zjednoczonych. Co więcej, w przypadku konfliktu interesów Niemcy i Francja - jak pokazuje to praktyka - wybierają realizację własnych interesów, zwłaszcza gospodarczych, wbrew interesom unijnym, starając się przy tym zreinterpretować swoje interesy w zgodzie $z$ normami i wartościami unijnymi oraz redefiniować interes europejski w zgodzie z własnym interesem gospodarczym (Cianciara, 2014, s. 192; Wong, Hill, 2011, s. 228-229).

$\mathrm{Na}$ tego typu zachowania nie powinno być przyzwolenia, bo jest to polityka destrukcyjna, która prowadzi do rozbicia jedności Unii i jej rozpadu. To sprawia, że Unia Europejska jest dziś słaba i lekceważona tak przez Stany Zjednoczone, jak i inne mocarstwa na czele z Chinami i Rosja. Amerykanie narzekaja, że Europejczycy nie chca im pomóc w utrzymaniu pokoju na świecie. Że pod ich parasolem Europa zbudowała sobie bezpieczny raj, za który nie chce zapłacić, że nie reaguje na zagrożenia. Od lat trwają dyskusje, czy Europa wymyśliła nowy ład i przeszła na wyższy poziom, do kolejnej fazy politycznego rozwoju, czy jedynie skorzystała z półwiecza życia pod amerykańskim kloszem? Odpowiedź pozostaje nieznana, bo nikt nie potrafi przewidzieć, jak zachowa się Unia, gdy stanie przed wielkim zagrożeniem. Czy się wówczas rozpadnie, czy wspólnie pokona wroga? Dopiero ta reakcja ujawni istotę Unii i pokaże jej prawdziwe oblicze (Madej, 2013, s. 244-271; Koziej, 2011, s. 76-84; Miszczak, 2007, s. 112-119).

Unia Europejska nadal konfrontuje się z bezprecedensowym w swej historii kryzysem finansowym, który przekształcił się w kryzys gospodarczy, a także w kryzys polityczny i symboliczny - kryzys legitymizacji władzy. Kryzys, dotyczący istoty konstrukcji UE, obnażył niemożność utrzymywania unii gospodarczej i walutowej w jej szczątkowej formie oraz unaocznił konieczność wzmocnienia koordynacji polityk gospodarczych państw członkowskich oraz zacieśnienia integracji w kierunku unii bankowej i fiskalnej, a co za tym idzie - unii politycznej. W UE wzrasta heterogeniczność, ale też na skutek kryzysu w strefie euro rosną presje na dalszy transfer kompetencji na poziom unijny, stąd też pogłębienie zróżnicowania wydaje się nieuniknione. Jednocześnie rośnie upolitycznienie integracji europejskiej i przestaje ona być procesem przede 
wszystkim biurokratycznym. Każdy nowy krok na drodze integracji generuje znaczące koszty polityczne dla poszczególnych państw członkowskich, co w konsekwencji oznacza nasilenie trendu do dalszego różnicowania się europejskiej integracji i tworzenie systemu hybrydowego, co jednak nie powinno wykluczać dyskusji o perspektywie federacyjnej (Leuffen, Rittberger, 2013).

Jednak różnicowanie się Unii napędzane jest nie tylko przez kryzys i pogłębianie integracji w strefie euro, na które część państw członkowskich nie jest gotowa, ale także przez potrzebę utrzymania pozycji Europy w wielobiegunowym świecie, która wymusza kontynuowanie polityki rozszerzenia i domaga się innowacyjnych form współpracy regionalnej. Jedną z nich może być zwiększenie elastyczności w zakresie przyjmowania unijnych reguł przez kolejnych członków i wypracowanie np. modelu częściowej integracji lub uprzywilejowanego partnerstwa dla tych państw, które nie pragną bądź nie są w stanie w przewidywalnej przyszłości spełnić wszystkich warunków pełnego członkostwa.

Tezą główną niniejszego artykułu jest stwierdzenie, że Unia Europejska wciąż dryfuje i znajduje się dziś w poważnych tarapatach, co może doprowadzić do jej katastrofy. Cała nadzieja w tym, że jej nowi przywódcy na czele z przewodniczącym Rady Europejskiej Donaldem Tuskiem i szefem Komisji Europejskiej Junkerem do tego nie dopuszczą i uczynią wszystko, aby UE wróciła na tory szybkiego rozwoju gospodarczego, politycznego i społecznego oraz stała się istotnym biegunem w multipolarnym świecie. W tym też celu UE musi wznowić proces jej poszerzania i pogłębiania oraz zacieśniać współpracę z NATO i Stanami Zjednoczonymi. Powinna też szukać możliwości porozumienia z Rosja, bez czego nie da się drogą pokojową rozwiązać problemu Ukrainy i pozostałych państw Europy Wschodniej.

Europa, zarówno zachodnia jej część, jak i Europa Środkowo-Wschodnia od 1989 roku do dnia dzisiejszego zmieniła się radykalnie i wciąż ulega dalszym przeobrażeniom, tak w aspekcie społecznym, politycznym, gospodarczym, jak i międzynarodowym. Europa Środkowo-Wschodnia uległa też podziałowi na kraje prozachodnie, aspirujące do Unii Europejskiej i państwa wiążące swoją przyszłość z Federacją Rosyjską. Już od ponad 25 lat na znacznym obszarze tego regionu dokonuje się transformacja ustrojowa, czyli budowa na gruzach ustroju komunistycznego nowego systemu społeczno-gospodarczego, zwanego demokratycznym, jeśli idzie o ustrój polityczny oraz kapitalistycznym, jeśli idzie o system ekonomiczny. Jednocześnie na obszarze tym trwają procesy integracyjne, które apogeum osiagnęly w 2004 roku, kiedy to aż osiem państw tego regionu zostało przyjętych do Unii Europejskiej, która rozpoczęła swoją działalność 1 listopada 1993 roku i dziś liczy już 28 członków. Z drugiej strony, w państwach takich jak Rosja, Ukraina czy Białoruś umocniły się rządy autorytarne, antydemokratyczne $\mathrm{i}$ anty unijne.

Utworzenie Unii Europejskiej, nowego podmiotu na arenie międzynarodowej, składającego się z suwerennych i demokratycznych państw, będącego efektem rozpadu starego, jałtańsko-poczdamskiego porządku geopolitycznego w Europie i na świecie, 
miało duże znaczenie dla Europy Środkowo-Wschodniej oraz jej poszczególnych państw na czele z Polską. Pociągnęło za sobą rekonfigurację w układzie sił w Europie i na świecie oraz przyspieszyło proces budowy nowego ładu globalnego. Europa przestała się dzielić na Wschód i Zachód oraz zaczęła się jednoczyć pod egidą Unii Europejskiej, która sukcesywnie ulegała poszerzeniu i pogłębieniu. Procesy te, istotne dla bezpieczeństwa poszczególnych państw i bezpieczeństwa międzynarodowego, budziły jednak niepokój w Rosji, zwłaszcza po 2000 roku, kiedy to na jej czele stanął ambitny polityk Władimir Putin, początkowo jako premier, a później prezydent, znowu premier i ponownie prezydent Federacji Rosyjskiej (Fiszer, 2010, s. 39-62; Harding, 2014).

Okres rządów Władimira Putina, de facto niekoronowanego władcy największego państwa na świecie, to lata obietnic i rozbudzonych nadziei na stopniową poprawę bytu materialnego Rosjan i przywrócenie Rosji statusu supermocarstwa. Politykę Putina można określić jako pragmatyczną i odidealizowaną. Swoimi wypowiedziami, zwłaszcza krytycznymi wobec Zachodu, Putin trafia w narodowo-patriotyczne nastawienie przeciętnego Rosjanina. „Rosja podniosła się z kolan!”, „Rosja znów zwycięża!” - to popularne, putinowskie hasła, które przyniosły mu społeczne poparcie i akceptację jego polityki wewnętrznej i zagranicznej. Bardzo szybko, wraz z rosnącą pewnością siebie W. Putin - i rosyjskie elity władzy - kreując Rosję na samodzielny i równie wpływowy co Stany Zjednoczone podmiot stosunków międzynarodowych, umocnił swoją pozycję przywódcy państwa i narodu rosyjskiego. Stał się najpopularniejszym politykiem w Rosji i budzącym respekt na całym świecie. Po aneksji Krymu popularność W. Putina w Rosji wzrosła z 60 do 85\%. Nie ulega watpliwości, że pod władzą Putina Rosjanie „odzyskali poczucie dumy narodowej”, a Rosja odbudowała swój autorytet na arenie międzynarodowej, której dziś - tak jak kiedyś Związku Radzieckiego - obawia się cały świat (Portnikow, 2008, s. 114-123; Piekło, 2009; Konończuk, 2007; Gessen, 2012).

Europejskie nadzieje, że Rosja może być partnerem Unii Europejskiej w walce o nowy, wielobiegunowy świat oparty na prawie międzynarodowym, okazały się w dobie rządów Putina płonne. Poparcie dla multilateralizmu oraz wielobiegunowości stanowiło po prostu taktyczną broń Moskwy w walce $\mathrm{z}$ hegemonią amerykańską. W rzeczywistości w sferze polityki zagranicznej Rosję cechuje instynkt bardziej amerykański niż europejski. Wierzy ona w siłe, unilateralizm oraz niepohamowane dążenie do zaspokojenia interesu narodowego. Dla Putina suwerenność nie jest prawem i nie oznacza miejsca wśród Narodów Zjednoczonych. Dla Putina suwerenność oznacza możliwości. Implikuje niezależność gospodarcza, siłę militarną oraz tożsamość kulturowa. W słowniku Putina ,mocarstwo suwerenne" to synonim ,wielkiego mocarstwa”. Podczas gdy UE powstała w odpowiedzi na zagrożenia ze strony nacjonalizmu i katastrofalnej rywalizacji między europejskimi państwami narodowościowymi w pierwszej połowie XX wieku, to obecna polityka zagraniczna Rosji jest odpowiedzią na zagrożenia ze strony polityki postnacjonalistycznej oraz problemy wynikające z rozpadu Związku Radzieckiego, z czym Putin i miliony Rosjan nie mogą pogodzić się do dnia dzisiejszego. Koszmary Europy mają swe źródło w tragicznych doświadczeniach lat trzydziestych XX wieku. Koszmarom Rosji ksztalt nadały doświadczenia rosyjskie z lat osiemdziesiątych i dziewięćdziesiątych XX wieku. Unia Europejska za główne źródło niestabilności w Eurazji uważała i uważa nadal brak demokracji. Natomiast 
Rosja odwrotnie, uważa, że słabe demokracje oraz zachodnia polityka eksportowania demokracji są głównymi przyczynami braku stabilności w obszarze poradzieckim. Nieuniknione więc było wcześniej czy później starcie tych dwóch kontrastujących ze sobą poglądów na ład europejski w XXI wieku (Krastev, 2009, s. 85-102; Asmus, 2008, s. 46 -64; Fiszer, 2013, s. 112-134).

Jak czytamy w znakomitej pracy na temat Rosji pod rządami Putina, której autorem jest brytyjski korespondent Luke Harding: „Ekspansjonizm Putina stanowi dzisiaj zapewne największe wyzwanie dla Zachodu, a zwłaszcza dla Unii Europejskiej, od zakończenia zimnej wojny. Po pięciu czy sześciu latach zaprzeczania Biały Dom przyznaje, że jego próby „resetu” stosunków z Rosją nie powiodly się. W unijnych ministerstwach spraw zagranicznych, akademiach wojskowych i ośrodkach analitycznych jest jasne, że potrzebne są nowe strategie radzenia sobie $z$ agresywną Rosją. Słowem kluczem nie jest już „zaangażowanie” - chociaż Europejczycy nie zrezygnowali z dialogu. Pojęcie, które na nowo nabiera podstawowego znaczenia w naszych czasach, pochodzi z wczesnych lat zimnej wojny: to „powstrzymanie” (Harding, 2014, s. 342).

Rozpad ZSRR w 1991 roku, który przyspieszył procesy integracyjne w Europie, zarazem zmniejszyl obszar panowania rosyjskiego, a to sprawiło, że imperium rosyjskie de facto przestało istnieć. $Z$ tym zaś nie mogły pogodzić się rosyjskie partie nacjonalistyczne i politycy na czele $\mathrm{z}$ Władimirem Putinem, zaliczani do tzw. homosowietikusów, czyli ludzi radzieckich, tęskniących za Związkiem Radzieckim i jego super mocarstwowym statusem na arenie międzynarodowej (Nowak, 2014). Tęsknoty te, a zarazem cele polityki międzynarodowej Władimira Putina trafnie prezentuje Andrzej Nowak, pisząc, że: „Wielkie Państwo - podkreślenie naturalnego charakteru jego geopolitycznej jedności i zarazem ciągłości jego historycznej tradycji, od IX do XXI wie$\mathrm{ku}$; uznanie centralnego $\mathrm{w}$ tej tradycji miejsca ZSRR, szczególnie w jego apogeum z okresu zwycięstwa w Wielkiej Wojnie Ojczyźnianej (od paktu Ribbentrop-Mołotow do Jałty); uwypuklenie ciagłego zagrożenia zewnętrznego, które sprowadza na Wielkie Państwo okresy Wielkiej Smuty, a wreszcie wskazanie potrzeby mobilizacji patriotycznej, która pod przewodnictwem mądrego przywódcy prowadzi do odrodzenia Wielkiego Państwa i jego globalnego znaczenia - oto w największym skrócie te motywy, które składają się na syntezę, do której zdaje się zmierzać oficjalna edukacja historyczna Rosji Putina" (Nowak, 2014, s. 203).

Jak już wspominałem, W. Putin jest niesamowicie popularny wśród Rosjan i jego głównym celem będzie tę popularność utrzymać jak najdłużej. Nie utrzyma jej przy pomocy cudu gospodarczego, bo na taki w Rosji się dziś nie zanosi, wręcz przeciwnie, grozi jej bankructwo i być może rozpad. Zatem będzie chciał ją utrzymać jako wódz armii. Najlepiej zwycięskiej, ale może i atakowanej przez „zdradziecki Zachód”. Dziś nikt takiej wojny nie chce, ale w przyszłości może być różnie i dlatego Unia Europejska musi się liczyć z taką możliwością i być do niej odpowiednio przygotowaną. To dzisiaj najważniejsze wyzwanie dla UE.

Dla Rosji najbardziej bolesna była utrata Ukrainy, największego kraju pod każdym względem w Europie Wschodniej. Ukraina, podobnie jak pozostałe kraje Europy Środkowo-Wschodniej, dla ZSRR stanowiła zaplecze surowcowe i rynek zbytu dla radzieckiego przemysłu. Rosja dlatego dążyła i nadal dąży do przekształcenia Ukrainy w federację, co ma ułatwić jej wpływ na politykę zarówno wewnętrzną, jak i zagra- 
niczną Ukrainy. Dla Rosji stosunki z Ukrainą są kluczowe z racji bliskich więzi historycznych, politycznych i kulturowych (Stryjek, 2014; Hrycak, 2009; Nowak, 2008, s. $83-88$ ).

Ponadto Ukraina ma duży potencjał destabilizowania i wpływania na układ sił nie tylko w skali Europy Wschodniej, ale również całego obszaru poradzieckiego. W związku z tym jest ona ważna z punktu widzenia ogólnoeuropejskich interesów Federacji Rosyjskiej. Dlatego, gdy obalono tam przychylnie nastawionego do Rosji Wiktora Janukowycza, Moskwa ruszyła do kontrataku, aby nie dopuścić do podpisania umowy o stowarzyszeniu Ukrainy z Unią Europejską i uniemożliwić w ten sposób ewentualną akcesję tego państwa do Wspólnoty, a później do NATO. Rosja obawia się bowiem, że dalsze poszerzanie UE, a także NATO doprowadzi do osłabienia jej wpływów nie tylko w Europie Środkowo-Wschodniej, ale w ogóle w całym świecie i uniemożliwi odbudowę rosyjskiego imperium, które w planach Władimira Putina ma stać się ważnym elementem (filarem) kształtującego się dziś nowego multipolarnego ładu globalnego (Dadak, 2014, s. 160-169; Kuźniar, 2014, s. 41-56).

Notabene, w literaturze przedmiotu występują różne, często skrajnie rozbieżne scenariusze i prognozy co do przyszłości Rosji i jej roli na świecie. Z jednej strony istnieja prognozy zakładające, że Rosja rozpadnie się i nie będzie odgrywała dużej roli na arenie międzynarodowej, a z drugiej strony zalicza się ją do nowych, wschodzących potęg (BRIC), które będą filarami przyszłego porządku globalnego (Gieorgica, Olędzka, 2013, s. 292-323; Kłosiński, 2010).

Do niedawna na tego typu spekulacjach korzystała Rosja, o współpracę z którą po 2000 roku zabiegały Stany Zjednoczone, Unia Europejska, Turcja, a także Chiny. Tymczasem Rosja pod rządami W. Putina starała się odzyskać mocarstwową pozycję na świecie i wpływy na Ukrainie, Białorusi i w innych krajach proradzieckich, również w Europie Środkowej i Południowej coraz silniej szantażując je oraz całą UE bronią energetyczną. Rosja próbowała wykorzystać słabnącą w tym czasie na arenie międzynarodowej pozycję Stanów Zjednoczonych, które w latach 2001-2014 uwikłały się w kosztowne wojny w Afganistanie i Iraku, które doprowadziły do animozji w łonie NATO i UE oraz do osłabienia sojuszu euroatlantyckiego. Z drugiej strony, Rosja, tak jak kiedyś Związek Radziecki wciąż jest tylko potegą nuklearną na ,glinianych”, gospodarczych nogach. Sankcje gospodarcze oraz spadek ceny ropy naftowej i gazu spowodowały, że Rosja dziś stoi w obliczu ogromnych problemów gospodarczych, które mogą doprowadzić do potężnego kryzysu społeczno-politycznego i odsunięcia Władimira Putina od władzy lub zmuszą go do podjęcia współpracy z Unią Europejską oraz Stanami Zjednoczonymi i zakończenia wojny na Ukrainie.

Prognozy dotyczące przyszłości Rosji i jej roli w budowie nowego ładu światowego są dziś bardzo trudne do obiektywnego opracowania, bowiem polityka zagraniczna tego państwa zawsze słabo poddawała się wymogom uwarunkowań zewnętrznych i niemal zawsze była pochodną polityki wewnętrznej. Wektory aktywności międzynarodowej Rosji były z reguły wzmocnieniem, uzupełnieniem i kontynuacją działań podejmowanych przez jej przywódcę $\mathrm{w}$ ramach funkcjonującego systemu politycznego. Jej głównym celem było i jest nadal uzyskanie określonych efektów wewnątrz samego systemu, a efekty uzyskane w jego otoczeniu traktowane są w sposób służebny. Dziś takim celem dla Putina jest zachowanie popularności wśród coraz bardziej spauperyzo- 
wanego i niezadowolonego społeczeństwa rosyjskiego oraz utrzymanie władzy za wszelką cenę w swoich rękach. Sytuacja obecna w Rosji i Putina przypomina tą z początków XX wieku, kiedy zacofany i opóźniony w rozwoju gospodarczym kraj, w którym narastało rewolucyjne wrzenie, car Mikołaj II próbował ratować poprzez sprowokowanie wojny z Japonią (1904-1905), a co dla niego i Rosji ostatecznie skończyło się katastrofą w 1917 roku.

Dziś Władimir Putin nie chce dopuścić do tego, by Rosja powtórzyła los Związku Radzieckiego i za wszelką cenę chce przywrócić jej miejsce na globalnej scenie. Z tej perspektywy Ukraina jest dla W. Putina wielkim wyzwaniem, gdyż jak trafnie zauważa Adam D. Rotfeld: „Jeśli powiedzie się tam ustrojowa transformacja, ustanowione będą rządy prawa, decentralizacja i demokracja, to w przestrzeni postsowieckiej powstanie nie tylko nowy punkt odniesienia i nowa konfiguracja, ale też wielu Rosjan uwierzy, że zmiana na lepsze jest możliwa w ich kraju. Przykład z Kijowa będzie zaraźliwy. [...] To, że ulica może pokazać czerwoną kartkę tym, którzy sprawują władzę, jest w Moskwie postrzegane jako większe zagrożenie niż tak często komentowana geopolityka czy geostrategia" (Ukraina, 2015, s. 18).

Aneksja Krymu i wojna Rosji z Ukrainą pociągnęły za sobą dalszą polaryzację państw Europy Środkowo-Wschodniej, gdzie dziś sytuacja jest zupełnie inna niż była 11 lat temu, a to z kolei nie jest bez znaczenia dla całej UE i jej przyszłości, która stoi pod znakiem zapytania. Podczas gdy Polska postrzegała ten konflikt w kategoriach „twardego" bezpieczeństwa, z naciskiem na zagrożenie militarne, to dla Czech, Węgier i Słowacji głównym wyzwaniem była przyszłość ich współpracy gospodarczo-energetycznej z Rosją. Już dawno nie funkcjonuje tutaj ani tzw. Trójkąt Wyszehradzki, ani Trójkąt Weimarski, a polityka zagraniczna premiera Orbana na Węgrzech pokazuje, że model liberalnej demokracji może zostać w środku unijnej Europy zanegowany. Czechy i Słowacja, podobnie jak Wegry ciążą dziś ku Rosji i dogadują się z Władimirem Putinem. Litwa od 1 stycznia 2015 roku przystąpiła do strefy euro i ma fatalne stosunki z Polską, która bezpowrotnie straciła szansę, aby stać się liderem Europy Środkowo-Wschodniej (Janicki, Władyka, 2015, s. 13-15). Co więcej, wzmocnienie pozycji Polski dzięki jej aktywności i współpracy z krajami Europy Środkowo-Wschodniej mogło też być ważnym atutem w kształtowaniu jej relacji z europejskimi potęgami, głównie z Niemcami i Francją, a także z Rosją. Tę szansę zmarnował ówczesny minister spraw zagranicznych RP Radosław Sikorski, dla którego głównym kierunkiem stała się UE, ze szczególną rolą Niemiec. Ogłoszenie przez ministra R. Sikorskiego końca tzw. ,polityki jagiellońskiej" przyjęte zostało jako rezygnacja z aktywnej polityki w Europie Środkowo-Wschodniej i odwrócenie się od mniejszych graczy na rzecz zacieśniania relacji z Niemcami i Francją (Ukielski, 2010, s. 364-365; Priorytety, 2012).

Z drugiej zaś strony, jak trafnie pisze cytowany już Luke Harding: „Dwadzieścia pięć lat po tym, jak w czerwcu 1989 roku Solidarność w Polsce zmiotła rządzących komunistów w wyborach, które zmieniły oblicze Europy, podziały między W schodem a Zachodem rysują się wyraźniej niż kiedykolwiek wcześniej. Polska, Czechy i Węgry są w NATO od 15 lat, a w Unii Europejskiej od dekady, wraz z państwami bałtyckimi. W tym okresie wszystkie te kraje kwitną. To prawdziwe historie sukcesu - pod względem rozwoju demokratycznego, gospodarczego, instytucjonalnego. Ale poza unijne 
byłe republiki upadłego Związku Radzieckiego to zupełnie inna, mniej szczęśliwa historia. Cofają się w rozwoju. Represyjny sposób działania Rosji służy jako szablon dla innych regionalnych przywódców, w tym dla Janukowycza, przed jego obaleniem" (Harding, 2014, s. 342; Wojnicki, 2014, s. 7-19).

Obecna polityka zagraniczna Władimira Putina - moim zdaniem - jest krótkowzroczna i przyniesie Rosji jeszcze większą izolację nie tylko w Europie, ale również na całym świecie. Przyspieszy, wbrew oczekiwaniom Moskwy, tworzenie się wrogiego Rosji, nowoczesnego państwa i narodu ukraińskiego, które w przyszłości może pełnić rolę lidera w Europie Środkowo-Wschodniej i stać się wzorem dla Białorusi czy Mołdawii, a także innych państw poradzieckich. Trudności gospodarcze, które potęguje awanturnicza polityka Rosji, moga - jak już pisałem - doprowadzić do poważnego kryzysu politycznego w tym kraju na miarę tego, który dotknął Związek Radziecki w drugiej połowie lat 80. XX wieku i wraz z wojną w Afganistanie w latach 1979-1989 przyspieszył jego rozpad w 1991 roku. Nie jest to więc wymarzona perspektywa dla Rosji, ale nie napawa to też optymizmem, jeśli idzie o UE i jej przyszłość, która - jak już wspominałem - stoi pod wielkim znakiem zapytania. Nie należy bowiem wykluczyć, że Rosja rozpęta pod byle pretekstem wojnę na dużą skalę w Europie, która może doprowadzić do rozpadu Unii Europejskiej.

\section{Bibliografia}

Asmus R. D. (2008), Europe's Ekstern Promise. Rethinking NATO and EU Enlargement, „Foreign Affairs", January/February.

Baczyński J. (2011), Czy porwiemy Europe??, „Polityka”, 6.07.-12.07.2011.

Beck U. (2009), Europa kosmopolityczna: spoleczeństwo i polityka w drugiej nowoczesności, Warszawa.

Beetham D., Lord Ch. (1998), Legitymacy and the European Union, London-New York.

Bania R., Zdulski R. (2015), Wyzwania i problemy wspólczesnych stosunków międzynarodowych, Łódź.

Bielecki T. (2015), Brytyjskie chmury nad Unia, „Gazeta Wyborcza”, 9-10.05.2015.

Bocian A. F. (2013), Globalizacja - Polityka - Etyka (tom IV), Bialystok.

Cianciara A. (2014), Gospodarcze uwarunkowania polityki wschodniej Niemiec i Francji, „Myśl Ekonomiczna i Polityczna", nr 2(45).

Czaputowicz J. (2007), Teorie stosunków międzynarodowych. Krytyka i systematyzacja, Warszawa

Czarnecki M. (2015), Wielki sukces Camerona, „Gazeta Wyborcza”, 9-10.05.2015.

Czech M. (2015), Kreml straszy świat wojnq, „Gazeta Wyborcza”, 9.03.2015.

Dadak K. (2014), Rosja, Ukraina i historyczna szansa dla Polski, „Arcana”, nr 120.

Emmerson M., Balfour R., Corthaut T., Wouters J., Kaczyński P. M., Renard T. (2011), Upgrading the EU's Role as Global Actor, Brussels.

Finkelstein L. S. (1995), What is global governance, „Global Governance”, nr 1.

Fiszer J. M. (2010), Wtadimir Putin - dlaczego zaufata mu cała Rosja? Specyficzne formy przywództwa politycznego, w: Przywództwo i elity polityczne w krajach WNP, red. T. Bodio, W. Jakubowski, Warszawa. 
Fiszer J. M. (2014), Czy państwo demokratyczne może być wzorem dla przyszlej Unii Europejskiej?, „Myśl Ekonomiczna i Polityczna”, nr 1(44).

Fiszer J. M. (2013), Bezpieczeństwo międzynarodowe w multipolarnym ladzie globalnym ze szczególnym uwzględnieniem roli Rosji, „Myśl Ekonomiczna i Polityczna”, nr 4(43).

Friedman G. (2012), Nastepna dekada. Gdzie byliśmy i dokad zmierzamy, Kraków.

Garczewski K. (2015), Niemcy we wspótczesnych stosunkach międzynarodowych-regionalne przywództwo, globalne ambicje, w: Wyzwania i problemy wspólczesnych stosunków międzynarodowych, red. R. Bania, K. Zdulski, Łódź.

Gessen M. (2012), Putin. Czlowiek bez twarzy, Warszawa.

Gieorgica J. P., Olędzka J. (2013), Wschodni sąsiedzi Polski: rosyjskie perspektywy nowego ladu światowego, w: Perspektywy nowego ladu światowego, red. L. Pastusiak, Warszawa.

Gravier M. (2011), Empire vs. Federation: which path for Europe?, „Journal of Political Power”, nr 7.

Grosse T. G. (2014), W oczekiwaniu na rewolucje, „Rzeczpospolita”, 22.07.2014.

Góralczyk B. (2014), Unia Europejska jako aktor na scenie globalnej. Razem czy osobno?, Warszawa.

Harding L. (2014), Mafijne państwo Putina, Kraków.

Holland M. (2002), The European Union and the Third Word, New York.

Hrycak J. (2000), Historia Ukrainy 1772-1999. Narodziny nowoczesnego narodu, Lublin.

Janicki M., Władyka W. (2015), Przedrzeźniacze, „Polityka”, 28.01-3.02.2015.

Karpienia M. (2013), Kryzys gospodarczy a kraje strefy BRIC, w: Globalizacja - Polityka - Etyka, tom IV, red. A. F. Bocian, Białystok.

Kłosiński K. A. (2010), Rosja: ambicje i możliwości w XXI wieku, Lublin.

Kołodziejczyk K. (2013), Stosunki Unii Europejskiej z grupq państw Afryki, Karaibów i Pacyfiku, Warszawa.

Konończuk W. (2007), Imperium Putina, Warszawa.

Koziej S. (2011), Potrzeba nowelizacji strategii bezpieczeństwa Unii Europejskiej, „Bezpieczeństwo Narodowe", nr IV (20).

Kranz J., Wyrozumska A. (2012), Powierzenie Unii Europejskiej niektórych kompetencji a Traktat fiskalny, „Państwo i Prawo”, nr 7.

Krastev I. (2009), Kryzys pozimnowojennego tadu europejskiego, „Nowa Europa”, nr 1(8).

Krzemiński A. (2014), Niemcy na huśtawce, „Polityka”, 30.07-5.07.2014.

Kubin T. (2014), Legitymizacja systemu instytucjonalnego Unii Europejskiej, Katowice.

Kuźniar R. (2014), Europa i porzadek międzynarodowy, „Stosunki Międzynarodowe - International Relations", $\mathrm{nr} 2$ (t. 50).

Leuffen D., Rittberger B., Schimmelfennig F. (2013), Differentiated Integration: Explaining Variation in the European Union, Houndmills Basingstoke.

Lipschutz R. D. (1997), From Place to Planet: Local Knowledge and Global Environmental Governance, no. 3 .

Łoś-Nowak T. (2011), O potrzebie rekonstrukcji przestrzeni badawczej w nauce o stosunkach międzynarodowych. Refleksje natury polityczno-normatywnej, systemowej i metaforycznej, „Przegląd Politologiczny", nr 1.

Malendowski W. (2010), Suwerenność państw w procesie integracji europejskiej, „Przegląd Politologiczny", $\mathrm{nr} 4$.

Madej M. (2013), Wplyw udzialu w Wspólnej Polityce Bezpieczeństwa i Obrony na polska politykę bezpieczeństwa, w: Polska w Unii Europejskiej. Bilans dekady, red. F. Tereszkiewicz, Warszawa. 
Miszczak K. (2007), Wspólna Polityka Zagraniczna i Bezpieczeństwa, „Sprawy Międzynarodowe”, nr 4.

Mniej Europy, więcej Europy (2014), Z Iwanem Kreszczewem rozmawia Adam Leszczyński, „Gazeta Wyborcza", 31.05-1.06.2014.

Mroziewicz K. (2014), Duzi chca być jeszcze więksi, „Polityka”, nr 38.

Nowak A. (2008), Putin. Źródla imperialnej agresji, Warszawa.

Nowak A. (2008), Pokusy rosyjskiej geopolityki, „Arcana”, nr 44(2).

Opinia Doradczego Komitetu Prawnego przy Ministrze Spraw Zagranicznych RP w sprawie przytaczenia Pólwyspu Krymskiego do Federacji Rosyjskiej w świetle prawa międzynarodowego (2014), „Sprawy Międzynarodowe”, nr 3.

Ostrowski M. (2014), Koniec marzen,, „Polityka”, 4-10.06.2014.

Piekło J. (2009), Rosja w kryzysie a sen o imperium - polska perspektywa, „Analizy i Opinie”, nr 95.

Pietraś M., Marzęda K. (2008), Hybrydowość późnowestwalskiego ladu międzynarodowego, Lublin.

Portnikow W. (2008), Wladca z przypadku, „Nowa Europa Wschodnia”, nr 1.

Priorytety polskiej polityki zagranicznej 2012-2016 (2012), Warszawa.

Prus J. (2015), Defilada mitów, „Polityka”, 6-12.05.2015.

Rewizorski M. (2015), Agora interesów. G 20 i wylanianie się globalnego zarzadzania, Warszawa.

Ruszkowski J., Wojnicz L. (2013), Multi-Level Governance w Unii Europejskiej, Szczecin-Warszawa.

Schulz M. (2014), Skrepowany OLBRZYM. Ostatnia szansa Europy, Warszawa.

Sila rzadzi światem (2015), Z Richardem Pipesem rozmawia Michał Potocki, „Dziennik Gazeta Prawna", 20-22.03.2015.

Smoczyński W. (2011), Europa się chwieje, „Polityka”, 29.07-5.07.2011.

Stryjek T. (2014), Ukraina przed końcem historii. Szkice o polityce państw wobec pamięci, Warszawa.

Ukielski P. (2010), Polska pozycja w Unii Europejskiej a relacje Polski z Czechami, Slowacja i Wegrami, w: Rzeczpospolita na arenie międzynarodowej. Idee i praktyczne dylematy polityki zagranicznej, red. J. Kloczkowski, T. Żukowski, Warszawa-Kraków.

Ukraina potrzebuje pieniędzy, nie broni (2015), Z prof. Adamem D. Rotfeldem rozmawia Bartosz T. Wieleński, „Gazeta Wyborcza”, 14-15.02.2015.

Wojnicki J. (2014), Europeizacja czy transformacja - ewolucje systemów politycznych Europy Środkowej i Wschodniej, „Przegląd Politologiczny”, nr 2.

Wong R., Hill Ch. (2011), National and Foreign Policies: Towards Europeanization, London-New York.

Wójcik Ł. (2015), Więzień Kremla, „Polityka”, 1-6.01.2015.

Zięba R. (2014), Międzynarodowe implikacje kryzysu ukraińskiego, „Stosunki Międzynarodowe - International Relations", $\mathrm{nr} 2$ (t. 50).

\section{Streszczenie}

Nie ulega wątpliwości, że Unia Europejska, będąca efektem europejskiej integracji jest w historii stosunków międzynarodowych bezprecedensowym podmiotem. Jest symbolem nowej, jednoczącej się Europy, która po negatywnych doświadezeniach postanowiła stać się kontynentem bezpiecznym, a więc wyeliminować raz na zawsze wojnę z życia jej państw i narodów. Niestety, idei ,wiecznego pokoju”, o czym marzyło wielu polityków i filozofów do dnia dzisiejszego nie udało się do końca zmaterializować. Co więcej, niedawne wojny na Bałkanach 
i obecna wojna rosyjsko-ukraińska tę ideę weiąż uniemożliwiają wprowadzić do stosunków międzynarodowych w Europie.

Celem niniejszego artykułu jest pokazanie Unii Europejskiej dziś, po dziesięciu latach od poszerzenia w 2004 roku jej składu o kolejne dziesięć państw, w tym aż osiem z byłego bloku wschodniego. Artykuł ten ukazuje atuty i słabości UE, która choć uległa dzięki temu poszerzeniu na Wschód daleko idącemu wzmocnieniu, to jednak dziś nie radzi sobie $\mathrm{z}$ wieloma problemami ekonomicznymi, politycznymi, społecznymi i międzynarodowymi. W artykule próbuję dać odpowiedź na wiele pytań dotyczących współczesnej UE, m.in. dlaczego tak się dzieje i jakie są tego przyczyny oraz jakie dla niej są perspektywy w XXI wieku. Tezą główną jest tutaj stwierdzenie, że UE wymaga kapitalnego remontu, tak, aby mogła dalej rozwijać się i być motorem integracji Europy. Jeśli zaś to nie nastapi, to UE zacznie się rozpadać i w końcu rozpadnie się lub stanie się co najwyżej strefą wolnego handlu.

Slowa kluczowe: Unia Europejska, integracja, kryzys finansowy, ład międzynarodowy, Zachód, Rosja, Ukraina

The European Union at present, and its uncertain future. Part I

\section{Summary}

There is no doubt that the European Union, which is the result of European integration, is an unprecedented entity in the history of international relations. It is a symbol of a new, united Europe, which, after negative experiences, decided to become a safe continent, and therefore eliminate once and for all war from the life of its states and nations. Unfortunately, the idea of "eternal peace,' which many politicians and philosophers dreamed about, has failed to be fully implemented to this day. Moreover, the recent war in the Balkans and the current Russian-Ukrainian war still make this idea impossible in international relations in Europe.

The purpose of this paper is to present the European Union today, ten years after its 2004 enlargement by a further ten countries, including eight from the former Eastern bloc. The paper shows the strengths and weaknesses of the EU, which - although significantly strengthened by the Eastern enlargement - still cannot cope with many economic, political, social and international problems. The author of this paper tries to come up with answers to many questions concerning the present EU: why is this happening, what are the reasons for it and what are the prospects for the EU in the $21^{\text {st }}$ century. The main thesis is that the EU needs overhauling, so it can continue to grow and be an engine of European integration. If this does not happen, though, the EU will begin to crumble and eventually disintegrate, or become no more than a free trade zone.

Key words: European Union, integration, financial crisis, international order, West, Russia, Ukraine 
